\title{
Formulation and Evaluation of Multidose Propofol Nanoemulsion Using Statistically Designed Experiments
}

\author{
Sidhartha Sankar Hota, ${ }^{1,3,}{ }^{*}$ Satyanarayan Pattnaik ${ }^{2}$ and Subrata Mallick ${ }^{1}$ \\ ${ }^{1}$ School of Pharmaceutical Sciences, Siksha 'O' Anusandhan (Deemed to be University), \\ Bhubaneswar 751003, Odisha, India. \\ ${ }^{2}$ Talla Padmavathi College of Pharmacy, Orus, Warangal, Telangana, India. \\ ${ }^{3}$ Zenotech Laboratories Ltd., Hyderabad, Telangana, India. \\ *Corresponding author: E-mail: sshota@rediffmail.com, profsmallick@gmail.com
}

Received: 08-19-2019

\begin{abstract}
Despite of the clinical, scientific, and commercial development, many patients complain about pain on the intravenous injection of propofol. Present work was undertaken to develop a stable multi-dose propofol nano-emulsion using $3^{2}$ full factorial design which is supposed to be associated with less anticipated pain during intravenous administration. Propofol was incorporated in the mixture of disodium edetate, sodium oleate, thioglycerol, glycerol, egg lecithin, soyabean oil and medium chain triglyceride oil, and homogenization was continued at controlled temperature of $20^{\circ} \mathrm{C}$. The product did not show any significant change in visible extraneous particulate matter, $\mathrm{pH}$, osmolality, bacterial endo-toxin, sterility, high performance liquid chromatography (HPLC) their stability and impurities after exposing at $40{ }^{\circ} \mathrm{C}$ for 3 and 6 months. Homogenization at 850 bar pressure of 30 min duration produced $174 \mathrm{~nm}$ particles with $-53.6 \mathrm{mV}$ zeta potential indicating its stability.
\end{abstract}

Keywords: Homogenization; nano-emulsion; propofol; statistical design of experiment.

\section{Introduction}

From the time of World War-II, anesthesiology got its importance for induction in combating casualties. The core objectives in developing injectable formulation are solubility, stability, and systemic tolerability. Osmolality is a potential factor for local tissue tolerability of an injectable drug product which would ideally be similar to that of the body fluid. Propofol is widely used for anesthesia. ${ }^{1,2}$ However, propofol is associated with pain at the administration site of the intravenous (IV) injection which is the substantial setback in clinical anesthesiology for smooth induction of general anesthesia. ${ }^{3,4}$ Various strategies have been reported to diminish the prevalence of pain by the addition of lidocaine, pethidine, fentanyl, alfentanil, remifentanil, butorphanol, thiopental etc. to propofol but no significant success has yet been achieved..$^{5-7}$ The induction of anesthesia needs a single dose of $1-5 \mathrm{mg} / \mathrm{kg}$ and maintenance dose of $50-250 \mathrm{mcg} / \mathrm{Kg} / \mathrm{min}$. Frequent dosing may be required for the entire operation period of in- fusion. ${ }^{8}$ Attempts were also taken to minimize the pain by increasing the rate of infusion at 2.5 to $5 \mathrm{ml}$ every $5 \mathrm{sec}$ onds compared to the normal rate of infusion (20 drops/ minute) but managing pain was still not possible. ${ }^{9-11}$

Commercially available propofol emulsions vary in particle size and lies somewhere around $300 \mathrm{~nm} .{ }^{5,12,13} \mathrm{Re}-$ duction in particle size of propofol may reduce pain upon its intravenous administration. Particle size reduction presented lower free fraction of propofol and a tendency to a lower incidence of pain. ${ }^{14} \mathrm{~A}$ lot of momentum in the recent past has been observed in fabricating nano-sized drug particles by top-down method using high pressure homogenization. Li et al., formulated microemulsion using pluronic F68, propylene glycol and saline, and produced a droplet size of about $300 \mathrm{~nm} \cdot{ }^{13}$ Ethyl butyrate being a short chain fatty (C-4, fewer than six carbons) acid showed higher drug release but deprived stability. Whereas, soybean oil, a larger molecule exhibited lower partitioning with excellent emulsion stability. Propofol emulsions formulated with mixtures of ethyl butyrate and soybean oil 
were kinetically stable with reduced aqueous phase drug concentration. ${ }^{15-17}$ No significant differences in pharmacokinetics and sedation properties were observed on comparison to a commercial soy-based propofol emulsion. ${ }^{18}$ To decrease the amount of free propofol in the aqueous phase propofol emulsions were fabricated with medium and long-chain triglycerides (MCT/LCT). ${ }^{19-22}$ Heat generated during processing of a propofol product can swiftly induce microbial growth. ${ }^{20}$ It was evident from a randomized double-blind clinical trial that pain on injection was reduced with small particle size lipid emulsion of propofol. ${ }^{23}$ Soybean oil, glycerol, egg lecithin, and disodium edetate are present in the propofol innovator product (Diprivan, Astra Zeneca), and the combination of triglycerides and phospholipids in the formulation reduces the chance of free propofol concentration. ${ }^{24-26}$

Multi-dose propofol oil in water stable nano-emulsion has been developed complying USP specifications with an intention to decrease the particle size, which is supposed to cause less pain. Propofol nano-emulsions were fabricated with and without sodium oleate using controlled homogenization technique. Process duration and homogenization pressure have been optimized for obtaining stable nano-emulsion of reduced particle size.

\section{Experimental}

\section{1. Materials}

Propofol was received as a kind gift sample from Themis Medicare, Gujarat, India. Soybean oil (Lipoid purified soybean oil 700), MCT (medium chain triglycerides) oil, Egg lecithin (Lipoid E80), and sodium Oleate (Lipoid Sodium Oleate B) were collected from Lipoid GMBH, Germany. Glycerols, thioglycerol, benzyl alcohol, disodium edetate, sodium hydroxide were sourced from Sigma Aldrich / Merck India. Capsule and membrane filters were from Millipore, India. Clear tubular glass vials were procured from Schott Kaisha, India and Bromobutyl stoppers were from West Pharma, Singapore. Freshly prepared double distilled water was used whenever required. All other reagents used were of analytic grade.

\section{2. Formulation Development and Optimization}

Preliminary studies were performed to characterize the active and inactive substances for their various physicochemical properties. Solubility and compatibility of the drug with other excipients were determined. The drug substance was thoroughly mixed with each of the excipients (except sodium hydroxide) in 1:1 ratio and were exposed at $50{ }^{\circ} \mathrm{C}$ for 2 weeks and observed for any change due to the impact of temperature and humidity.

The entire work was carried out in a Class-100 area, under the LAF (Lamellar Air Flow, Accumax, India) cabinet, pre fumigated with $\mathrm{H}_{2} \mathrm{O}_{2}$. All the containers and accessories were autoclaved at $121^{\circ} \mathrm{C}, 15 \mathrm{psi}$ of pressure for $15 \mathrm{~min}$ prior to use. The dissolution of each and every formulation ingredient was checked. The speed of stirring, temperature and time were recorded. The manufacturing temperature was fixed by observing the solubility of propofol. The formulation $\mathrm{pH}$ was observed by checking the $\mathrm{pH}$ at each step with reference to $\mathrm{pH}$ drift studies performed by adjusting the $\mathrm{pH}$ of the bulk to different $\mathrm{pH}$ values within the range.

After execution of several trials of process temperature, homogenization time, formulation stability and $\mathrm{mi}-$ crobial attributes the optimized formulation was finalized with the inactive ingredients as: soyabean oil $(50 \mathrm{mg} / \mathrm{mL})$, MCT oil $(50 \mathrm{mg} / \mathrm{mL})$, egg lecithin $(13 \mathrm{mg} / \mathrm{mL})$, sodium oleate $(0.52 \mathrm{mg} / \mathrm{mL})$, glycerol $(22.5 \mathrm{mg} / \mathrm{mL})$, benzyl alcohol $(1 \mathrm{mg} / \mathrm{mL})$, disodium edetate $(0.05 \mathrm{mg} / \mathrm{mL})$, and thioglycerol $(1 \mathrm{mg} / \mathrm{mL})$. Disodium edetate, sodium oleate, thioglycerol, glycerol and Egg lecithin were added to water at about $20^{\circ} \mathrm{C}$ and stirred for 10 min with an overhead stirrer and filtered using a $0.45 \mu \mathrm{m}$ PVDF filter (Durapore, Millipore). Soyabean oil and MCT oil were mixed with an overhead stirrer for $5 \mathrm{~min}$ in a separate beaker and propofol $(10 \mathrm{mg} / \mathrm{mL})$ was added to it and mixed further for 5 $\mathrm{min}$. Both these phases were mixed for $5 \mathrm{~min}$ and sodium hydroxide was added for $\mathrm{pH}$ adjustment to 6.5. Then homogenized using the Lab scale homogenizer (Lark Ultrasonic Cell Crusher, India) until it was filterable through the $0.22 \mu \mathrm{m}$ PVDF filter (Durapore, Millipore). Throughout the process, the temperature was maintained at about $25^{\circ} \mathrm{C}$. The laboratory scale optimized process was executed in triplicate for reproducibility and to monitor the robustness of the formulae and process with confirmation of various analytical parameters.

Scale up of the manufacturing process of the optimized batch was carried out in a class-100 area (room temperature $20 \pm 2{ }^{\circ} \mathrm{C}$ ) using large scale equipments, e.g., mixing/pressure vessels, homogenizer (Goma Engineering, Mumbai, India), cooling jackets, vertical stirrers, filling and sealing machines. Homogenization ${ }^{27,28}$ was continued for 30,60 or $90 \mathrm{~min}$ at 650,750 or 850 bar as per the levels of the factorial design (Table 1).

Benzyl alcohol, thioglycerol and disodium edetate were dissolved in water at about $20^{\circ} \mathrm{C}$ and egg lecithin was added with continued stirring for $30 \mathrm{~min}$. Other ingredients of the oil phase were properly mixed and filtered through $0.45 \mu \mathrm{m}$ filter and was poured in to the aqueous phase for homogenisation from 650 to 850 bar pressure for 30-90 min.

Droplet size distributions and zeta potential of emulsion at each interval of time and pressure were obtained using dynamic light scattering (Malvern Nano-ZS, USA). ${ }^{29}$

\section{3. Statistical Design of Experiment}

Varieties of factorial designs of experiments can be used in drug development. These different factors and 
their interactions should be evaluated to predict their effects on the final formulation and its robustness. ${ }^{30}$ An appropriate mathematical model (experimental design) can give necessary information for the fabrication process and product development. ${ }^{31}$

A three-level factorial design was used for optimization of the homogenization process. In the present study, pressure during homogenization $\left(\mathrm{X}_{1}\right)$ and duration (time) of homogenization $\left(\mathrm{X}_{2}\right)$ were chosen as independent variables. The particle size $(Z)$ following homogenization was estimated as dependent response (Table 1). Homogenization pressure was evaluated at 650 bar $(-1), 750$ bar (0), and 850 bar $(+1)$, while duration of homogenization was evaluated at $30 \mathrm{~min}(-1), 60 \mathrm{~min}(0)$, and $90 \mathrm{~min}(+1)$. From the preliminary trials, the levels for these two parameters were finalized. To evaluate the responses incorporating interactive and polynomial terms in a statistical model was explained.

$$
\begin{aligned}
\mathrm{Y}= & \mathrm{b}_{0}+\mathrm{b}_{1} \mathrm{X}_{1}+\mathrm{b}_{2} \mathrm{X}_{2}+\mathrm{b}_{12} \mathrm{X}_{1} \mathrm{X}_{2}+\mathrm{b}_{11} \mathrm{X}_{1} \mathrm{X}_{2}+ \\
& +\mathrm{b}_{22} \mathrm{X}_{2} \mathrm{X}_{2} \ldots \ldots \ldots \ldots
\end{aligned}
$$

where, $\mathrm{Y}$ is the dependent variable, $\mathrm{b} 0$ is the arithmetic mean response of the nine runs, and $b_{i}\left(b_{1}, b_{2}, b_{12}, b_{11}\right.$ and $\mathrm{b}_{22}$ ) are the estimated coefficient for the corresponding factor $\mathrm{X}_{\mathrm{i}}\left(\mathrm{X}_{1}, \mathrm{X}_{2}, \mathrm{X}_{1} \mathrm{X}_{2}, \mathrm{X}_{1} \mathrm{X}_{1}\right.$ and $\left.\mathrm{X}_{2} \mathrm{X}_{2}\right)$, in which the average result of changing one factor at a time from its low to high value is represented. The change in response is shown by the interaction term $\left(\mathrm{X}_{1} \mathrm{X}_{2}\right)$ when two factors are changed simultaneously. To investigate nonlinearity the polynomial terms $\left(\mathrm{X}_{1} \mathrm{X}_{1}, \mathrm{X}_{2} \mathrm{X}_{2}\right)$ are included. For the generation and evaluation of the statistical experimental design Design-Expert software (Version. 10.0.1, Stat-Ease Inc., Minneapolis, USA) was used. ${ }^{32}$

\section{4. Polyvinylidene Fluoride (PVDF) Filter Integrity Test}

Sterilizing-grade hydrophilic PVDF disposable filter (Durapore membrane disc, Millipore Corp.) disc (0.45 and $0.22 \mu \mathrm{m}$ ) was used for product integrity test. The filter was incubated with the product in a closed vessel at $40^{\circ} \mathrm{C}$ for a contact time of 4 hours. The filter was then investigated for change in the physical characteristics such as bubble point, membrane thickness and burst pressure. The integrity testing of the filter elements were wetted with the optimized formulation.

\section{5. Leachable Extracts}

Presence of any leachable extracts and the loss of components due to adsorption were estimated by soaking the filter membrane with the optimized formulation in relation to the fresh formulation.

\section{6. Filling and Sealing}

The product was then passed through a membrane filter holder with $2.0 \& 0.45 \mu \mathrm{m}$ filters at $0.3-0.4$ bar pressure, filled in $50 \mathrm{~mL}$ sterilized vials under nitrogen and sealed.

\section{7. Color and Clarity}

The color and clarity parameters were assessed by comparing the test solution with a standard reference suspension. Briefly, standard stock opalescence was prepared by adding $1 \%(\mathrm{w} / \mathrm{v})$ hydrazine sulphate in water $(25 \mathrm{ml})$ to a $10 \%(\mathrm{w} / \mathrm{v})$ solution of Hexamine in water $(25$

\begin{tabular}{|c|c|c|c|}
\hline \multirow[t]{2}{*}{ Run } & \multicolumn{2}{|c|}{ Process factors } & \multirow{2}{*}{ 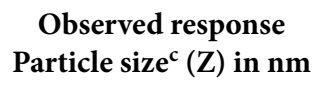 } \\
\hline & Pressure $\left(\mathrm{X}_{1}\right)^{\mathrm{a}}$ & Duration $\left(\mathrm{X}_{2}\right)^{\mathrm{b}}$ & \\
\hline 1 & 1.00 & 0.00 & $182( \pm 8.1)$ \\
\hline 2 & -1.00 & -1.00 & $328( \pm 4.8)$ \\
\hline 3 & -1.00 & 1.00 & $302( \pm 6)$ \\
\hline 4 & 0.00 & 0.00 & $206( \pm 5)$ \\
\hline 5 & -1.00 & 0.00 & $302( \pm 5)$ \\
\hline 6 & 0.00 & 0.00 & $210( \pm 3)$ \\
\hline 7 & 1.00 & -1.00 & $176( \pm 3)$ \\
\hline 8 & 0.00 & 0.00 & $203( \pm 3)$ \\
\hline 9 & 0.00 & 0.00 & $205( \pm 5)$ \\
\hline 10 & 0.00 & 0.00 & $209( \pm 3)$ \\
\hline 11 & 0.00 & 1.00 & $206( \pm 3)$ \\
\hline 12 & 1.00 & 1.00 & $207( \pm 5)$ \\
\hline 13 & 0.00 & -1.00 & $222( \pm 3)$ \\
\hline
\end{tabular}

Table 1. Process variables and the observed response using $3^{2}$ factorial design

${ }^{a}$ Levels of homogenization pressure $\left(\mathrm{X}_{1}\right)$ as 650 bars $(-1), 750$ bars $(0)$ and 850 bars $(+1)$.

${ }^{\mathrm{b}}$ Levels of homogenization duration $\left(\mathrm{X}_{2}\right)$ as $30 \mathrm{~min}(-1), 60 \mathrm{~min}(0)$ and $90 \mathrm{~min}(+1)$.

${ }^{c}$ Data shown are mean of three determinations and figure in the parentheses indicates standard error of the mean. 
$\mathrm{ml}$ ); mixed well and allowed to stand for 24 hours. Standard opalescence was prepared by diluting $15 \mathrm{ml}$ of the standard stock opalescence solution to $1000 \mathrm{ml}$ with water and further, the reference suspension was prepared by diluting $5 \mathrm{ml}$ standard of opalescence with $95 \mathrm{ml}$ of water. Each of $20 \mathrm{ml}$ of test solution and reference suspension was transferred to a colorless, transparent and neutral glass tube, and the absorbance was measured at $430 \mathrm{~nm}$ using a UV-visible spectrophotometer (Jasco V-630, USA). The clarity of the solution was compared with standard opalescence produced by hydrazine sulphate in a transparent, neutral glass tube against a black background by viewing in diffused daylight down the vertical axis. $^{33}$

\section{8. pH, Osmolality, Particulate Matter Density and Specific Gravity}

$\mathrm{pH}$ and Osmolality of propofol nano emulsion were measured employing a $\mathrm{pH}$ meter $(720 \mathrm{~A}$; Thermo Orion, USA) and Cryoscopic Osmometer (Osmomat 030; Gonotec $\mathrm{GmbH}$, Germany) respectively. Presence of any particulate matter was observed through the light obscuration counter sensor (APSS-2000 Liquid Particle Counter, Particle Measuring Systems, USA). Density and specific gravity of the emulsion were tested by using a density / specific gravity meter-DA-100 (Kyoto Electronics, Japan). ${ }^{33-35}$

\section{9. HPLC Assay}

For all types of drug estimation the chromatographic procedure was carried out using high performance liquid chromatography (Jasco LC-Net II/ADC, USA). Stainless steel column of $5 \mathrm{~mm}$ internal diameter $(15 \mathrm{~cm} \times 4.6 \mathrm{~mm}$ long), packed with octadecylsilyl silica gel for chromatography $\mathrm{R}(5 \mu \mathrm{m})$ (Nucleosil C18) with a solvent system of orthophosphoric acid, water and acetonitrile at a ratio of 7:200:300 (by volume) was used as mobile phase at a flow rate of $1.2 \mathrm{~mL} / \mathrm{min}$. Each solution of $25 \mu \mathrm{L}$ was injected and the detector of the spectrophotometer was set at 210 $\mathrm{nm}$. Same method was followed taking $10 \mu \mathrm{L}$ of reference solution and continuing the chromatography for $15 \mathrm{~min}$ for the impurities.

\section{10. Multiple Piercing Resistance Study}

The final sterile formulation was filled in a sterile 50 $\mathrm{mL}$ clear tubular glass vial capped with a sterile bromobutyl stopper. The stopper was punctured with a sterile 22 gauge needle at $0^{\text {th }}, 8^{\text {th }}, 24^{\text {th }}, 32^{\text {nd }}, 48^{\text {th }}$ hours with a storage condition of $2-8{ }^{\circ} \mathrm{C}$ and sample $(2 \mathrm{~mL}$ each) was withdrawn for evaluation of sterility and bacterial endotoxin (BET) loads to ensure the products resistance to multiple piercing as BET are lipopolysaccharides associated with pathogenic Gram-negative shock

\section{11. Bacterial Challenge Test}

The product was collected from the sealed vials and filtered through a $0.45 \mu$ membrane. The membrane was rinsed with $0.1 \%$ peptone water and placed over the pre incubated tryptone soya agar plates. The agar plates were incubated at $20-25^{\circ} \mathrm{C}$ for 3 days followed by $30-35^{\circ} \mathrm{C}$ for further 2 days and the numbers of colonies forming units were counted. Aseptic techniques were followed throughout the process.

Limulus Amoebocyte Lysate (LAL) test was performed to detect the presence of any bacterial endotoxin. All the test tubes, micropipette tips and volumetric pipettes were depyrogenated by autoclaving $\left(121^{\circ} \mathrm{C}\right.$ and 15 psi of pressure for $30 \mathrm{~min}$ ) before testing. Glassware were rinsed with water and are made endotoxin free by dry heat sterilization at $250^{\circ} \mathrm{C}$ for one hour. Both $\mathrm{NaOH}$ and $\mathrm{HCl}$ solution (each $0.1 \mathrm{~N}$ ) were prepared and autoclaved at 121 ${ }^{\circ} \mathrm{C}, 15 \mathrm{psi}$ of pressure for $30 \mathrm{~min} .{ }^{51}$

\section{12. Stability Studies}

Droplet size distribution of the emulsion after 3 freeze-thaw cycles $\left(16\right.$ hours at $-5^{\circ} \mathrm{C}, 8$ hours at $25^{\circ} \mathrm{C}$ ) were examined using dynamic light scattering (Malvern Nano-ZS, USA). The hydrodynamic size and zeta potential obtained were compared to that of the freshly prepared samples. Filled and sealed vials $(50 \mathrm{~mL})$ were stored at 40 ${ }^{\circ} \mathrm{C} \pm 2{ }^{\circ} \mathrm{C} / 75 \% \mathrm{RH} \pm 5 \% \mathrm{RH}$ for 6 months at upright and inverted positions and evaluated for stability. Emulsions were investigated visually at the end of the $3^{\text {rd }}$ and $6^{\text {th }}$ month for any phase separation and creaming and allowed for further testing. ${ }^{15}$

\section{Results and Discussion}

\section{1. Formulation Development}

Three reproducible batches of propofol nano-emulsions were developed varying the formulation ingredients and homogenization parameters (Table 1) to optimize the product. Taking the ingredients, pre mixing of oil and water phases with an overhead shaft stirrer resulted in foam formation which hindered a proper mixing of the ingredients. Oil soluble ingredients were mixed and filtered using $0.45 \mu \mathrm{m}$ filter. Aqueous soluble ingredients were mixed separately and filtered through $2.0 \mu \mathrm{m}$ filter as egg lecithin micelles cannot be filtered through $0.45 \mu \mathrm{m}$ filter. Then both phases were mixed separately and then homogenized at up to 850 bar pressure for up to $90 \mathrm{~min}$ as per (Table 1). Formulations were fabricated with and without sodium oleate to interpret its interference in BET aggravation. However, sodium oleate was found to be a non-interfering substance. The single dose commercial products may not contain anti-oxidant/preservative; even if the ingredients are susceptible to oxidation and support microbial 
Table 2. Stability analysis of the product

\begin{tabular}{|c|c|c|c|c|}
\hline \multirow{2}{*}{ Test parameters } & \multirow{2}{*}{ Specification } & \multirow{2}{*}{ Initial sample } & \multicolumn{2}{|c|}{ Stability sample } \\
\hline & & & $3^{\text {rd }}$ Month & $6^{\text {th }}$ Month \\
\hline Description & $\begin{array}{l}\text { Clear colorless solution free from visible } \\
\text { extraneous particulate matter }\end{array}$ & Complies & Complies & Complies \\
\hline $\begin{array}{l}\text { Absorbance at } 430 \mathrm{~nm} \\
\text { (Color and clarity) }\end{array}$ & Not more than 0.200 & 0.108 & 0.112 & 0.120 \\
\hline Clarity of the solution & $\begin{array}{l}\text { Opalescence not more pronounced than } \\
\text { the reference suspension }\end{array}$ & Complies & Complies & Complies \\
\hline $\mathrm{pH}$ & Between 6.0 and 8.5 & 6.4 & 6.5 & 6.8 \\
\hline Osmolality & Between $260-320 \mathrm{mOsm} / \mathrm{Kg}$ & 304 & 306 & 310 \\
\hline Hydrodynamic size (nm) & - & 174 & 222 & 227 \\
\hline Zeta potential (mV) & - & -53.6 & -47.1 & -45.8 \\
\hline Bacterial Endotoxins & Not more than $0.5 \mathrm{EU} / \mathrm{mg}$ of Propofol & None detected & None detected & None detected \\
\hline Particulate matter i) $\geq 10 \mu$ & Not more than 6000 & 120 & 148 & 129 \\
\hline per container $\quad$ ii) $\geq 25 \mu$ & Not more than 600 & 11 & 14 & 11 \\
\hline Sterility & $\begin{array}{l}\text { No microbial growth should be observed in } \\
\text { the test sample after } 14 \text { days of preparation }\end{array}$ & No growth & No growth & No growth \\
\hline HPLC assay & Between 90-110 & 100.02 & 98.96 & 96.74 \\
\hline $\begin{array}{ll}\text { Impurities (\%) } & \text { Total } \\
& \text { impurities }\end{array}$ & Not more than 1.0 & 0.56 & 0.7 & 0.71 \\
\hline
\end{tabular}

growth. ${ }^{47-48}$ Formulation trials were also executed incorporating an anti-oxidant and a preservative which are generally recognized as safe (GRAS) for parenteral use. The product characterization data are presented in Table 2.

In the fabrication process addition of egg lecithin to cooled water and stirring for $30 \mathrm{~min}$ may promote the growth of microorganisms as egg lecithin is a supportive nutrient. ${ }^{36,49}$ This process was revised by the addition of preservatives first and then egg lecithin. This had a bacteriostatic effect on the liquid and microbial growth was arrested leading to improvement in BET values (Table 3).

With an objective to select a sterilization filter, PVDF capsule and membrane filters were tested to establish a product wetted bubble point values in contrast to the water wetted values. The levels of leachable substances were examined at this part of the study that might be associated with the use of filters in contact with the product.

Initially, the liquid bulk product was tried for sterilization by filtration using capsule filter. However, difficulties were observed in passing this product through the capsule filter. The product was then passed through 2.0 \& $0.45 \mu \mathrm{m}$ membrane filters using a membrane filter holder at low pressure (0.3-0.4 bar). The bubble point (filter integrity) value was found to be 1.5 bar which was in agreement with its viscosity. ${ }^{37,38,46}$ Based on this confidence levels, the filtered product was filled into vials. Product failed sterility testing as the filtration train with $2.0 \& 0.45 \mu \mathrm{m}$ filter did not meet the usage of a series of filters sufficiently. The microbiological studies for sterility and endotoxin loads confirmed that the product remained intact as of its initial potency.

The sample meets the requirements of the test if the observation of the test is negative when tested at a dilution not exceeding Maximum Valid Dilution (MVD). No microbial growth was observed in the test sample after 14 days of preparation. BET levels were found acceptable in the product i.e., less than the fixed limits of $0.5 \mathrm{EU} / \mathrm{mg}$ (Table 2 and Table 3 ). The addition of the preservative and the method of separate filtration process of the different phases were able to reduce the microbial load of soyabean oil (12 $\mathrm{CFU} / \mathrm{gm}$ ) and egg lecithin (40 CFU/gm). This result enabled the product to resist multiple piercing for up to 48 hours. This confirmed the content integrity of the product for multiple dosing for over a period of 48 hours in a controlled environment.

$$
M V D=\frac{\text { Endotoxin limit } * \text { concentration of product }(\mathrm{mg} / \mathrm{mL})}{\text { Lysate sensitivity }(\lambda)}
$$


Table 3. Bacterial endotoxin testing after multiple piercing of the same vial

\begin{tabular}{|c|c|c|c|c|c|c|}
\hline \multirow{2}{*}{$\begin{array}{c}\text { Time point of } \\
\text { piercing the vial }(h)\end{array}$} & \multicolumn{4}{|c|}{ Endotoxin dilution (EU/mL) } & \multirow{2}{*}{$\begin{array}{l}\text { LRW (Negative } \\
\text { Control) }\end{array}$} & \multirow{2}{*}{$\begin{array}{c}\text { End } \\
\text { point }\end{array}$} \\
\hline & $2.0 \lambda(0.06)$ & $1.0 \lambda(0.03)$ & $0.5 \lambda(0.015)$ & $0.25 \lambda(0.007)$ & & \\
\hline 0 & + & + & - & - & - & 0.12 \\
\hline 8 & + & + & - & - & - & 0.12 \\
\hline 24 & + & + & + & - & - & 0.06 \\
\hline 32 & + & + & + & - & - & 0.06 \\
\hline 48 & + & + & + & - & - & 0.06 \\
\hline
\end{tabular}

Where, $\lambda=$ labelled sensitivity of LAL Reagent (EU per mL) LRW = LAL (Limulus Amoebocyte Lysate) reagent water

The levels of $\mathrm{pH}$ and Osmolality were well in their specific limits and have not changed significantly in accelerated stability condition, and supposed to be in the tolerable level. ${ }^{39}$ Non appearances of creaming in the product till 1 month were further exposed to freeze thaw cycles and other accelerated conditions. A continuous homogenization with cooling jackets for 30 minutes at 850 bar pressure generated droplets of $174 \mathrm{~nm}$ mean diameter and $-53.6 \mathrm{mV}$ zeta potential. Under the stressed conditions of freezing and thawing the droplet size distribution of the product remained almost unchanged, and exhibited a size of $175 \mathrm{~nm}$ and $-47.1 \mathrm{mV}$ zeta potential.

Prior to Bacterial Challenge Test (BCT), a viability test was performed in order to establish the bactericidal effect of the product. The viability test helps determine the most appropriate BCT methodology. After the total exposure time, no more than 1 log reduction of the initial bacterial concentration was observed and hence the product was considered to be non-bactericidal.

\section{2. Homogenization Process Optimization Using DoE}

Statistically designed experiments have been exploited widely for pharmaceutical process optimization includ- ing formulation parameter screening activities. ${ }^{40-42}$ In the present research a $3^{2}$ full factorial design was used to optimize the homogenization process parameters. ${ }^{43}$ The homogenization process is very crucial in the development of a stable nano-emulsion, and the key process variables are homogenization duration and pressure. As per DoE software suggestion 13 runs were taken with the selected two numeric continuous process variables. The response variable chosen was the particle size of propofol post homogenization. Since, no aliases were found for quadratic model, response surface quadratic model was used safely for navigation through the model. ${ }^{44}$ The highest order polynomial was selected as the sequential model sum of squares (Type 1) where the additional terms were significant $(p<0.05)$ and the model was not aliased. The cubic model was found to be aliased and hence the model was not selected (Table 4). Quadratic model was fitted to the data $(\mathrm{P}<0.05)$ based on the model summary statistics including the adjusted $R^{2}$ and predicted $R^{2}$ for interpretation of the homogenization process response and particle size $(\mathrm{Z})$ (Table 4).

The model and the model terms like $\mathrm{X}_{1}, \mathrm{X}_{1} \mathrm{X}_{2}, \mathrm{X}_{1}^{2}$ and $\mathrm{X}_{2}^{2}$ are significant as understood by the analysis of variance (ANOVA) for the response surface quadratic

Table 4. Statistical model analysis of particle size

\begin{tabular}{|c|c|c|c|c|}
\hline \multicolumn{5}{|c|}{ Sequential model sum of squares for } \\
\hline Source & $\begin{array}{c}\text { Sum } \\
\text { of Squares }\end{array}$ & $\begin{array}{c}\text { Degree } \\
\text { of freedom }(\mathrm{Df})\end{array}$ & F-Value & p-Value \\
\hline Mean vs Total & $6.749 \mathrm{E}+005$ & 1 & & \\
\hline Linear vs Mean & 21999.00 & 2 & 16.52 & 0.0007 \\
\hline 2FI vs Linear & 702.25 & 1 & 1.06 & 0.3298 \\
\hline Quadratic vs 2FI & 5813.52 & 2 & 144.39 & $<0.0001$ \\
\hline Cubic $^{\mathbf{a}}$ vs Quadratic & 91.50 & 2 & 4.63 & 0.0728 \\
\hline Residual & 49.42 & 5 & & \\
\hline Total & $7.035 \mathrm{E}+005$ & 13 & & \\
\hline \multicolumn{5}{|c|}{ Design model summary statistics } \\
\hline Source & \multicolumn{2}{|c|}{ Adjusted $\mathrm{R}^{2}$} & \multicolumn{2}{|c|}{ Predicted $\mathrm{R}^{2}$} \\
\hline Linear & \multicolumn{2}{|c|}{0.7212} & \multicolumn{2}{|c|}{0.5013} \\
\hline $2 \mathrm{FI}$ & \multicolumn{2}{|c|}{0.7229} & \multicolumn{2}{|c|}{0.0023} \\
\hline Quadratic & \multicolumn{2}{|c|}{0.9916} & \multicolumn{2}{|c|}{0.9619} \\
\hline Cubic & \multicolumn{2}{|c|}{0.9959} & \multicolumn{2}{|c|}{0.9325} \\
\hline
\end{tabular}

${ }^{\mathrm{a}} \mathrm{Cubic}$ model is aliased and hence is not selected. 
Table 5. Analysis of variance

\begin{tabular}{|c|c|c|c|c|c|c|}
\hline \multicolumn{4}{|c|}{ Response Surface Quadratic model } & \multicolumn{3}{|c|}{ Standardized mean effect } \\
\hline Source & $\begin{array}{l}\text { Sum of } \\
\text { Squares }\end{array}$ & F-Value & p-Value ${ }^{*}$ & $\begin{array}{c}\text { Coefficient } \\
\text { Estimate }\end{array}$ & $\begin{array}{l}\text { Standard } \\
\text { Error }\end{array}$ & $\begin{array}{l}\text { Standardized } \\
\text { mean effect }\end{array}$ \\
\hline Model & 28514.77 & 283.28 & $<0.0001$ & 205.93 & 1.86 & 110.71 \\
\hline $\mathrm{X} 1$ & 21961.50 & 1090.89 & $<0.0001$ & -60.50 & 1.83 & -33.06 \\
\hline $\mathrm{X} 2$ & 37.50 & 1.86 & 0.2146 & -2.50 & 1.83 & -1.36 \\
\hline $\mathrm{X} 1 \mathrm{X} 2$ & 702.25 & 34.88 & 0.0006 & 13.25 & 2.24 & 5.91 \\
\hline $\mathrm{X} 12$ & 3934.09 & 195.42 & $<0.0001$ & 37.74 & 2.70 & 13.97 \\
\hline $\mathrm{X} 22$ & 262.09 & 13.02 & 0.0086 & 9.74 & 2.70 & 3.60 \\
\hline
\end{tabular}

${ }^{*}$ p-Values $<0.05$ indicates significant terms

model (Table 5). The fitted polynomial equations relating to the responses were generated using Design Expert software and are given below.

Particle Size $=+205.93-60.49 * \mathrm{X}_{1}-2.49 * \mathrm{X}_{2}+13.24$ * $\mathrm{X}_{1} \mathrm{X}_{2}+37.74 * \mathrm{X}_{1}^{2}+9.74 * \mathrm{X}_{2}^{2}$

The coefficient estimate and standardized main effects (SMEs) for the dependent responses are listed in Table 6 . SME values were calculated by dividing the main effects by the standard error of the main effects. In addition, three dimensional response surface plots were presented to estimate the effects of the mixture components on each response. Results of multiple regression analysis and SMEs revealed that the process variables had statistically significant influence on the dependent variables $(\mathrm{p}<$ 0.05 , Table 5). The SME values clearly indicated that the homogenization pressure $\left(\mathrm{X}_{1}\right)$ is the most influential factor compared to the duration of homogenization $\left(\mathrm{X}_{2}\right)$ on the average particle size and can be visualized from the $3 \mathrm{D}$ surface plots (Figure 1) and contour plot (Figure 2). The surface response and contour plots are indicative of an op-

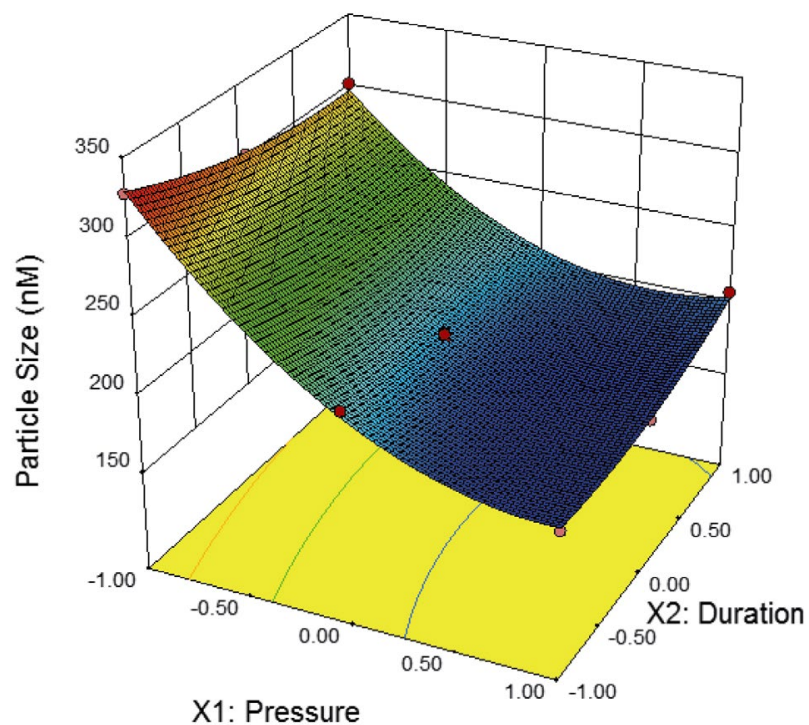

Figure 1.3D Surface response plot indicates the effect of homogenization pressure $\left(\mathrm{X}_{1}\right)$ and the duration of homogenization $\left(\mathrm{X}_{2}\right)$ on average particle size. timal point of resultant particle size beforehand of homogenization. Both the plots of DOE potentially predicted the systematic workflow. Average particle size yield was found to be $174 \mathrm{~nm}$ (Figure 3) with $30 \mathrm{~min}$ of homogenization at 850 bar pressure. Similar marketed formulations were reported of having much larger particles of around $300 \mathrm{~nm}^{5}$ compared to the present formulation and supposed to cause less pain while passing through the arteries. ${ }^{23}$

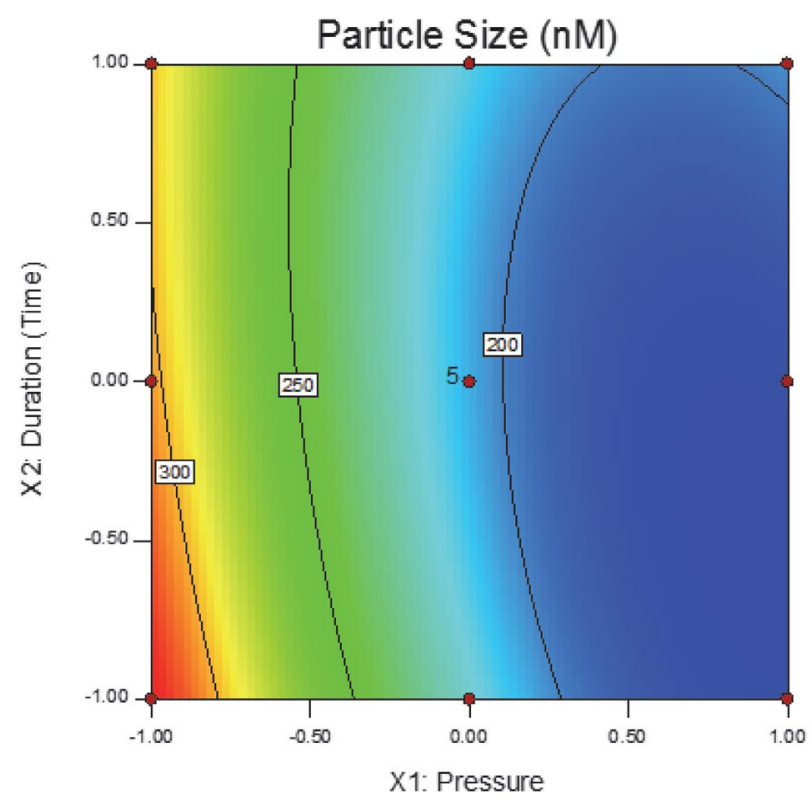

Figure 2. Contour plot indicating that the homogenization pressure $\left(\mathrm{X}_{1}\right)$ is the most influential factor compared to the duration of homogenization $\left(\mathrm{X}_{2}\right)$ on average particle size.

For parenteral emulsions droplet size and polydispersity index (PI) are vital physicochemical parameters as large particle size is clinically unacceptable. The formulation exhibited PI of 0.096 (Figure 3) which is well below the acceptable limit for parenteral emulsions 44,45 indicating high stability. The initial zeta potential $(-53.6 \mathrm{mV}$, Figure 4) of the product was found above $-40 \mathrm{mV}$ in accelerated stability condition of 6 months, which also implied its better stability. The stability indicating factors of the accel- 
erated condition confirmed with those of the initial strategic values and hence can have a better shelf life in controlled environmental conditions.

The HPLC chromatogram of initial formulation are reported in the Figures 5 indicating the retention time of

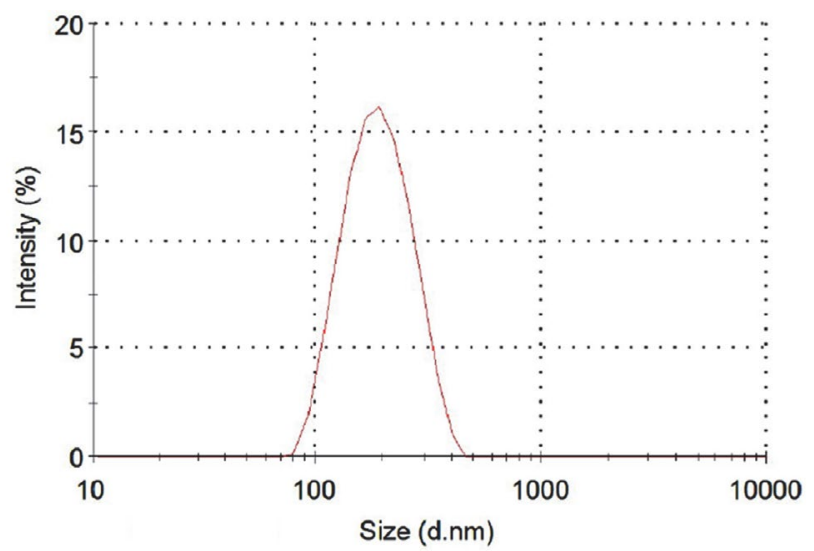

Figure 3. Hydrodynamic size distribution of the initial formulation

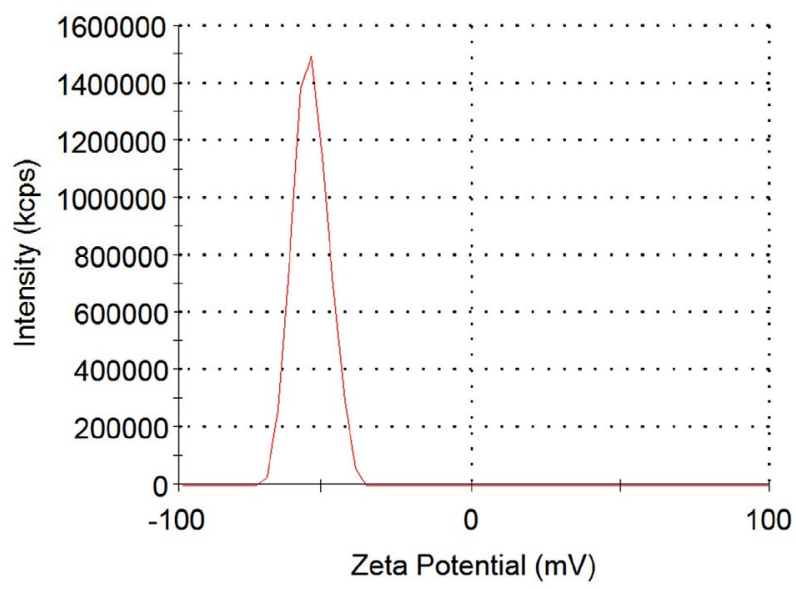

Figure 4. Zeta potential distribution of the initial formulation the active substance and other negligible peaks due to inactive substances and impurities. The assay of the formulation has shown the value in the prescribed range of $90-110 \%$ (Table 3, Figure 5) and the impurity levels (Table 3) remained below the threshold throughout the testing period.

\section{Conclusions}

Multi-dose propofol nano-emulsion was prepared with and without sodium oleate complying USP specifications and evaluated successfully using design of experiments. Controlled homogenization process could unable to influence the particle size significantly. The optimized process of homogenization at 850 bar of $30 \mathrm{~min}$ of duration produced $174 \mathrm{~nm}$ particles. PI and zeta potential of 0.096 and $-53.6 \mathrm{mV}$ respectively indicated highly stable product. The accelerated stress testing including freezing and thawing exhibited no significant change in the product. Further studies could be done to perform preclinical investigations in suitable animal models to assess the product.

\section{Acknowledgements}

The authors are very much grateful to the Honorable Prof. Manoj Ranjan Nayak, President, Siksha 'O' Anusandhan (Deemed to be University) for providing other facilities and encouragement. The authors are also thankful to Zenotech Laboratories Ltd for providing adequate facilities and support for the research work.

\section{References}

1. P. Pascale, M. R. Tramer, Anesth. Analg 2000, 90(4), 963-969. DOI:10.1213/00000539-200004000-00035

2. K. A. Desousa, Indian J. Pharmacol. 2016, 48, 617-23. DOI:10.4103/0253-7613.194845

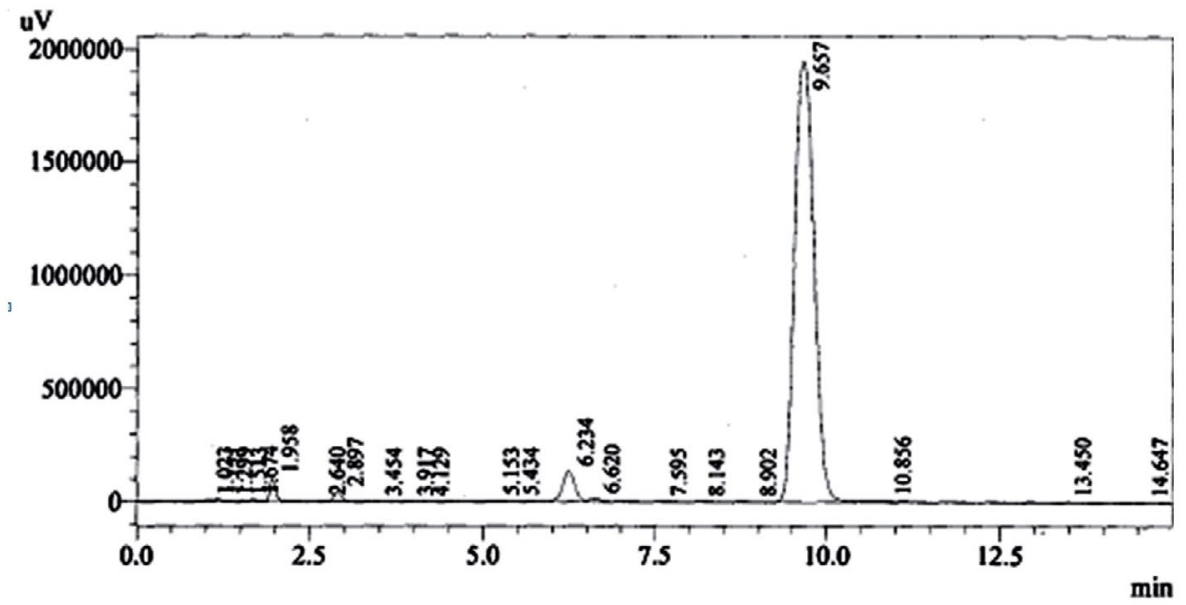

Figure 5. HPLC analysis for assay of the initial formulation 
3. E. Liljeroth, J. A. Keson, Acta. Anaesthesiol. Scand. 2005, 49, 248-251. DOI:10.1111/j.1399-6576.2004.00573.x

4. N. C. H. Sun, A. Y. C. Wong, M. G. Irwin, Anesth. Analg. 2005, 101, 675-678. DOI:10.1213/01.ANE.0000157564.91910.04

5. W. Gao, B. Sha, Z. Fan, Y. Liu, X. Shen, J. Nanomater 2016, Article ID 8486530, 8 pages.

6. B. Bachmann-mennenga, A. Ohlmer, H. Boedeker, M. Mann, B. Muhlenbruch, M. Heesen, Eur. J. Anaesthesiol. 2007, 24, 33-38. DOI:10.1097/00003643-200701000-00006

7. E. Kam, M. S. Abdul-Latif, A. McCluskey, Anaesthesia 2004, 59, 1167-1169. DOI:10.1111/j.1365-2044.2004.03964.x

8. W. S. Jellish, J. P. Leonetti, J. R. Murdoch, S. Fowles, J. Clin. Anesth. 1995, 7, 292-296.

DOI:10.1016/0952-8180(95)00030-L

9. R. P. F. Scott, D. A. Saunders, J. Norman, Anaesthesia 1988, 43, 492-4. DOI:10.1111/j.1365-2044.1988.tb06641.X

10. C. L. Huang, Y. P. Wang, Y. J. Cheng, L. Susetio, C. C. Liu, Anesth Analg 1995, 81, 1087-1088.

DOI:10.1097/00000539-199511000-00033

11. C. H. Tan, M. K. Onsiong, Anaesthesia 1998, 53, 468-476. DOI:10.1046/j.1365-2044.1998.00405.x

12. D. F. Driscoll, Pharm. Res. 2006, 23, 1959-1969. DOI:10.1007/s11095-006-9092-4

13. G. Li, Y. Fan, X. Li, X. Wang, Y. Li, Y. Liu, Int. J. Pharm. 2012, 425(1-2), 53-61. DOI:10.1016/j.ijpharm.2012.01.011

14. T. A. Rodrigues, R. A. Alexandrino, M. E. Kanczuk, J. L. Gozzani, L.A.S.T. Mathias, Rev Bras Anestesiol 2012, 62, 325-334. DOI:10.1016/S0034-7094(12)70133-2

15. R. Damitz, A. Chauhan, Int. J. Pharm. 2015, 486(1-2), 232241. DOI:10.1016/j.ijpharm.2015.03.057

16. A. Salman, M. Salman, F. Saricaoglu, J. Clin. Anesth. 2011, 23(4), 270-274. DOI:10.1016/j.jclinane.2010.09.008

17. A. Honarmand, M. Safavi, Acute. Pain. 2008, 10(1), 23-29. DOI:10.1016/j.acpain.2008.01.001

18. C. Tsagogiorgas, S. Theisinger, E. Heesch, J. Krebs, R. Holm, G. Beck, Int. J. Pharm. 2015, 486(1-2), 69-76.

DOI:10.1016/j.ijpharm.2015.03.037

19. R. Burimsittichai, K. Kumwilaisuk, S. Charuluxananan, W. Tingthanathikul, P. Premsamran, N. Sathapanawath, J Med Assoc Thai 2006, 89, 86-91.

20. M. Yamakage, S. Iwasaki, J. Satoh, A. Namiki, Anesth. Analg. 2005, 101(2), 385-388.

DOI:10.1213/01.ANE.0000154191.86608.AC

21. M. Perlstein, A. Aserin, E. Wachtel, N. Garti, Colloids Surf., B. 2015, 136, 282-290. DOI:10.1016/j.colsurfb.2015.08.044

22. T. Shimizu, S. Inomata, M. Tanaka, J. Clin. Anesth. 2011, 23(7), 540-543. DOI:10.1016/j.jclinane.2011.02.006

23. B. Krobbuaban, S. Diregpoke, S. Kumkeaw, M. Tanomsat, J. Med. Assoc. Thailand, 2005, 88 (10), 1401-5.

24. J. Carpenter, Propofol-based Anesthetic and Method of Making Same. U S Patent Number 6,150,423, date of patent November 21, 2000.

25. C. Jones, J. Platt, Pharmaceutical compositions of propofol and edetate. U S Patent Number 5,731,355, date of patent March 24, 1998.

26. J. Zhang, J. Ding, M. Luo, Propofol formulation with en- hanced microbial inhibition. U S Patent Number 6,399,087, date of patent June 4, 2002.

27. M Juttulapa, S Piriyaprasarth, H Takeuchi, P Sriamornsak, Asian J Pharm Sci, 2017, 21-27.

DOI:10.1016/j.ajps.2016.09.004

28. S Schultz, G Wagner, K Urban, J Ulrich, Chem Eng Technol, 2004, 27, 361-368. DOI:10.1002/ceat.200406111

29. M. Mlynarczyk, M. Sznitowska, D. W. Swietlikowska, Drug Dev. Ind. Pharm. 2008, 34, 355-362.

DOI:10.1080/03639040701657628

30. S. Pattnaik, K. Swain, P. Manaswini, E. Divyavani, J. V. Rao, V. Talla, S. K. Subudhi, J. Drug Delivery Sci. Technol. 2015, 29, 199-209. DOI:10.1016/j.jddst.2015.07.021

31. M. Tondar, M J Parsa, Y Yousefpour, A M Sharifi, S V ShetabBoushehri, Acta Chim. Slov. 2014, 61, 688-693.

32. S. Bohanec, T. R. Peterka, P. Blazic, R. Jurecic, J. Grmas, A. Krivec, J. Zakrajsek, Acta Chim. Slov. 2010, 57, 895-903.

33. The United States Pharmacopeia, National Formulary, Rockville (MD), United States Pharmacopeial Convention. 2012, 1061, 609-610.

34. The United States Pharmacopeia, National Formulary, Rockville (MD): United States Pharmacopeial Convention. 2012, 791:343-344.

35. The United States Pharmacopeia, National Formulary, Rockville (MD): United States Pharmacopeial Convention. 2012, 785, 335-336.

36. J. D. Kalen, J. I. Hirsch, K. A. Kurdziel, W. C. Eckelman, D. O. Kiesewetter, Appl Radiat Isot. 2007, 65(6), 696-700.

DOI:10.1016/j.apradiso.2006.10.015

37. F. Strachan, J. Mansel, R. Clutton, J. Small Anim. Pract. 2008, 49(4), 186-190. DOI:10.1111/j.1748-5827.2007.00473.x

38. B. K. Meyer, D. Vargas, PDA J Pharm Sci Technol 2006, 60, 248-253. DOI:10.2533/000942906777674886

39. I. Wachowski, D. T. Jolly, F. J. Hrazdil, J. C. Galbraith, M. Greacen, A. S. Clanachan, Anesth Analg 1999, 88, 209-212. DOI:10.1213/00000539-199901000-00039

40. A. Bottino, G. Capannelli, A. Comite, Desalination 2005, 183, 375-382. DOI:10.1016/j.desal.2005.03.040

41. K. Hayashi, K. Douhara, G. Kashino, Ann. Nucl. Med. 2014, 28, 586-592. DOI:10.1007/s12149-014-0830-0

42. W. Wang, Int. J. Pharm. 2015, 490, 308-315. DOI:10.1016/j.ijpharm.2015.05.069

43. S. Pattnaik, K. Swain, J. V. Rao, T. Varun, S. Mallick, Medicina, 2015, 51(4), 253-261. DOI:10.1016/j.medici.2015.07.002

44. S. Pattnaik, K. Swain, J. V. Rao, T. Varun, S. K. Subudhi, RSC. Adv. 2015, 5, 91960-91965. DOI:10.1039/C5RA20411A

45. S. Pattnaik, K. Swain, S. Mallick, Lat. Am. J. Pharm. 2009, 28, 62-69.

46. B. Jancic, M. Medenica, D. Ivanovic, A. Malenovic, Acta. Chim. Slov. 2007, 54, 49-54.

47. F. A. Araujo, R. G. Kelmann, B. V. Araujo, R. B. Finatto, H. F. Teixeira, L. S. Koester, Eur J Pharm Sci 2011, 42, 238-245. DOI:10.1016/j.ejps.2010.11.014

48. R. H. Muller, S. Schmidt, I. Buttle, A. Akkar, J. Schmitt, S. Bromer, Int. J. Pharm. 2004, 269, 293-302. DOI:10.1016/j. ijpharm.2003.09.019 
49. B. K. Meyer, A. NI, B. HU, L. Shi, J Pharm Sci 2007, 96, 31553167. DOI:10.1002/jps.20976

50. The United States Pharmacopeia, National Formulary, Rockville (MD): United States Pharmacopeial Convention. 2012, 4449-4450.
51. The United States Pharmacopeia, National Formulary, Rockville (MD): United States Pharmacopeial Convention. 2012, 71, 69-74.

\section{Povzetek}

Kljub kliničnemu, znanstvenemu in komercialnemu razvoju se mnogi bolniki pritožujejo zaradi bolečin pri intravenski injekciji propofola. Pričujoča raziskava je bila izvedena z namenom razviti stabilne večodmerne nano-emulzije propofola $\mathrm{z}$ uporabo celovitega $3^{2}$ faktorialnega modela, ki naj bi bil povezane $\mathrm{z}$ manj pričakovanimi bolečinami med intravenskim dajanjem propofola. Propofol je bil vgrajen v mešanico dinatrijevega edetata, natrijevega oleata, tioglicerola, glicerola, jajčnega lecitina, sojinega olja in trigliceridnih olj s srednjo dolžino verige. Homogenizacijo smo nadaljevali pri nadzorovani temperaturi $20^{\circ} \mathrm{C}$. Po izpostavitvi temperaturi $40^{\circ} \mathrm{C}$ za 3 in 6 mesecev izdelek ni vidno spremenil zunanjega videza, vrednosti $\mathrm{pH}$, osmolalnosti, bakterijskega endotoksina, sterilnosti in določitev nečistoč. Homogenizacija pri tlaku 850 bar je po 30 minutah vodila do delcev velikosti $174 \mathrm{~nm}$ in zeta potenciala $-63,6 \mathrm{mV}$, kar kaže na njegovo stabilnost.

Except when otherwise noted, articles in this journal are published under the terms and conditions of the Creative Commons Attribution 4.0 International License 